\title{
Sistem Pendukung Keputusan Rekomendasi Makanan Khas Sulawesi Utara yang Menunjang Diet
}

\author{
Fernando D. Sawel, Alicia A. E. Sinsuw, Muhamad D. Putro \\ Teknik Informatika Universitas Sam Ratulangi Manado, Indonesia. \\ nandosawel@gmail.com, aliciasinsuw@gmail.com,dwisnantoputro@gmail.com
}

\begin{abstract}
Abstrak - Makanan Khas Sulawesi Utara sebagian besar berasal dari lemak hewani, Banyak orang-orang pendatang, baik sedang melakukan wisata maupun ada yang tinggal untuk studi di manado, sehingga permasalahan yang terjadi pada makanan minahasa, membuat masayarkat sulawesi utara maupun pendatang atau yang sedang melakukan program diet penurunan berat badan, enggan untuk mengkonsumsi makanan khas minahasa yang bisa mengakibatkan kegemukan atau kelebihan kalori. Tujuan dan Manfaat dari aplikasi ini, untuk membuat aplikasi Sistem Pendukung Keputusan (SPK) Rekomendasi Makanan Khas Sulawesi Utara yang Menunjang Diet, Sehingga manfaatnya, masyarakat dapat mengetahui makanan khas sulawesi utara yang dapat menunjang diet. Kriteria untuk diet penurunan berat badan yang di digunakan dalam penilaian perbandingan berpasangan yaitu, Protein $40 \%$, Karbohidrat $50 \%$ dan Lemak $10 \%$. Langkah-langkah user dalam melihat informasi makanan yang di rekomendasikan untuk menunjang diet tersebut dengan cara memasukkan bobot penilaian dari setiap kriteria berdasarkan persentase diet, datadata yang telah dimasukkan akan di proses dan di lakukan perbandingan oleh sistem mengunakan perhitungan metode $\boldsymbol{A H P}$ (Analytical Hierarcy Process) untuk merekomendasi makanan yang menunjang diet, sehingga mendapatkan hasil rangking berupa data makanan dan berdasarkan tabel rangking bisa disimpulkan makanan yang paling baik untuk diet adalah Nasi Jaha dengan skor 54.49.
\end{abstract}

Kata kunci : SPK, Makanan Khas Sulawesi Utara, Protein, Karbohidrat, Lemak, Diet, $A H P$

\section{PENDAHULUAN}

Makanan dan kesehatan merupakan hal utama dalam hidup kita. Tanpa makan kita tidak akan dapat hidup. Dan tanpa kesehatan kita juga tidak akan hidup dengan tenang. Makanan adalah sumber kehidupan, tetapi makanan juga dapat menyebabkan terganggunya kesehatan. Maka sebagai makhluk hidup memerlukan makanan yang sehat agar hidup kita juga sehat. Makanan yang sehat tidak harus mahal tetapi yang sesuai dengan apa yang dibutuhkan oleh tubuh kita. Makanan yang kita makan harus memenuhi standar gizi dan kesehatan.Diet yang seimbang berarti mendapatkan jenis yang tepat dan jumlah makanan dan minuman untuk makanan seimbang untuk diet memasok nutrisi dan energi untuk menjaga sel-sel tubuh, jaringan, dan organ, dan untuk mendukung pertumbuhan dan juga perkembangan normal.

Masyarakat etnik Minahasa mempunyai suatu kebiasaan pesta yang diikuti dengan pesta makan atau makan makanan Minahasa yang sebagian besar berasal dari lemak hewani, selain itu, bahan - bahan untuk mengolah makanan minahasa sangat mudah di dapatkan. Banyak orang-orang pendatang, baik sedang melakukan wisata maupun ada yang tinggal untuk studi di manado, sehingga permasalahan yang terjadi pada makanan khas sulawesi utara membuat masayarkat sulawesi utara maupun pendatang atau yang sedang melakukan program diet penurunan berat badan, enggan untuk mengkonsumsi makanan khas minahasa yang bisa mengakibatkan kegemukan atau kelebihan kalori.Untuk mengatasi permasalahan tersebut, dibutuhkan sebuah sistem berbasis web yang dapat merekomendasikan makanan khas sulawesi utara yang menunjang diet.Dengan kriteria yang diberikan dan melalui perhitungan menggunakan metode AHP (Analytical Hierarchy Process).

\section{LANDASAN TEORI}

\section{A. Sistem Pendukung Keputusan (SPK)}

Prabowo (2012) Sistem pendukung keputusan merupakan penggabungan sumber - sumber kecerdasan individu dengan kemampuan komponen untuk memperbaiki kualitas keputusan. Sistem pendukung keputusan juga merupakan sistem informasi berbasis komputer untuk manajemen pengambilan keputusan yang menangani masalah - masalah semistruktur[5].

\section{B. AHP (Analytical Hierarchy Process)}

Jacobs (2014) AHP merupakan suatu model pendukung keputusan yang dikembangkan oleh Thomas L. Saaty. Model pendukung keputusan ini akan menguraikan masalah multi faktor atau multi kriteria yang kompleks menjadi suatu hirarki. Hirarki didefinisikan sebagai suatu representasi dari sebuah permasalahan yang kompleks dalam suatu struktur multi level dimana level pertama adalah tujuan, yang diikuti level faktor, kriteria, sub kriteria, dan seterusnya ke bawah hingga level terakhir dari alternatif. Dengan hirarki, suatu masalah yang 
kompleks dapat diuraikan ke dalam kelompok-kelompoknya yang kemudian diatur menjadi suatu bentuk hirarki sehingga permasalahan akan tampak lebih terstruktur dan sistematis[1].

\section{Prosedur Perhitungan AHP}

Ismoyo (2015) Pada dasarnya terdapat beberapa tahapan ataupun prosedur yang harus dilakukan dalam proses perhitungan bobot dengan metode $A H P$. Adapun tahap-tahap dalam proses perhitungan bobot antara lain :

- Menyusun hirarki dari permasalahan yang di hadapi, yaitu mendefinisikan masalah dan membentuk solusi yang di inginkan. Kemudian membuat struktur hirarki yang diawali dengan tujuan umum, dilanjutkan dengan kriteria dan alternatif-alternatif pada tingkatan yang paling bawah.

- Membuat matriks perbandingan berpasangan yang menggambarkan kontribusi relatif atau pengaruh setiap elemen terhadap masing-masing kriteria dengan kriteria lain, skala 1 sampai 9 adalah skala terbaik dalam membandingkan elemen.

- Pertimbangan-pertimbangan terhadap perbandingan berpasangan disintesis untuk memperoleh keseluruhan prioritas atau Total Priotiry Value (TPV).

- Menjumlahkan nilai-nilai dari setiap kolom pada matriks.

- Membagi setiap nilai dari kolom dengan total kolom yang bersangkutan untuk memperoleh normalisasi matriks, kemudian menjumlahkan nilai-nilai dari baris dan membaginya dengan jumlah elemen (n) atau kriteria untuk mendapatkan nilai prioritas $(T P V)$.

- Memeriksa konsistensi (Consistency Ratio atau CR) matriks perbandingan suatu kriteria. Matriks Perbandingan dinyatakan konsisten jika nilai $C R \leq 0.1$, tetapi nilai $C R>$ 0.1 maka pertimbangan yang dibuat perlu diperbaiki dan diteliti kembali.

- Bobot yang didapat dari nilai $T P V$ dikalikan dengan nilainilai awal elemen matriks perbandingan yang telah diubah menjadi bentuk desimal.

- Menjumlahkan nilai setiap baris yaitu nilai hasil perkalian $T P V$ dengan elemen matriks.

- Hasil dari penjumlahan baris dibagi dengan nilai $T P V$ setiap kriteria, sehingga di dapatkan nilai $\lambda$ mak setiap baris.

- Nilai rata-rata $\lambda$ maks didapat dengan cara menjumlahkan semua nilai $\lambda$ maks setiap baris dan dibagi dengan jumlah kriteria (n) seperti pada rumus berikut :

$\lambda$ maks $=(\lambda$ maks K1 $+\ldots+\ldots+\lambda$ maks Kn $) / \mathrm{n}$

\section{Keterangan :}

$\lambda$ maks $=$ nilai rata-rata dari keseluruhan kriteria $\mathrm{n}=$ jumlah kriteria dalam matriks perbandingan
- Setelah mendapatkan nilai $\lambda$ maks, langkah selanjutnya mencari nilai Consistency Index $(C I)$ dengan persamaan sebagai berikut :

$C I=(\lambda$ maks $-\mathrm{n}) /(\mathrm{n}-1)$

- Setelah CI didapat, maka langkah selanjutnya adalah menghitung nilai Consistency Ratio $(C R)$ dengan mengacu pada Random Index ( $R I)$ yang dapat diambil dengan ketentuan sesuai dengan jumlah kriteria yang di gunakan. Adapun rumus Consistency Ratio $(C R)$ adalah :

$C R=C I / R I$

Dimana, $C R=$ Consistency Ratio

$C I=$ Consistency Index

$R I=$ Random Index

D.Diet

Diet adalah mengatur asupan nutrisi dan mengatur kegiatan makan makanan untuk mencapai tujuan kesehatan tertentu atau menjaga berat badan agar terkontrol. Tujuan diet bagi sebagian orang bisa berbeda-beda. Ada sebagian yang melakukan diet untuk tujuan kesehatannya karena ajuran dokter atau disebabkan karena menderita penyakit tertentu, sedangkan sebagian lainnya melakukan diet karena bermasalah dengan berat badannya.

\section{E. Konsepsi Dasar UML}

Dharwiyanti (2003),Abstraksi konsep dasar $U M L$ yang terdiri dari structural classification, dynamic behavior, dan model management, bisa kita pahami dengan mudah apabila kita melihat gambar diatas dari Diagrams. Main concepts bisa kita pandang sebagai term yang akan muncul pada saat kita membuat diagram. Dan view adalah kategori dari diagaram tersebut.UML mendefinisikan diagram-diagram seperti, use case diagram, class diagram, statechart diagram, activity diagram, sequence diagram, collaboration diagram, component diagram, deployment diagram.

\section{F. PHP (Hypertext Preprocessor)}

Jaka P (2014), PHP: Hypertext Preprocessor (PHP) adalah bahasa skrip yang dapat ditanamkan atau disisipkan ke dalam HTML/PHP banyak digunakan untuk membuat situs web dinamis. Tujuan utama penggunaan bahasa ini adalah untuk memungkinkan perancang dan menulis halaman web menjadi dinamis dengan cepat. PHP pertama kali dibuat oleh Rasmus Lerdorf pada tahun 1995, seorang programmer C[2]. 
G. $M y S Q L$

Nuh (2012), MySQL adalah salah satu perangkat lunak Database Management System (DBMS) yang sering digunakan saat ini, yang didistribusikan secara gratis di bawah lisensi GPL (GNU General Public License). Sehingga setiap orang mudah untuk mendapatkan dan bebas untuk menggunakan $M y S Q L[4]$.

\section{METODOLOGI PENELITIAN}

\section{A. Metode Pengumpulan Data}

Metode pengumpulan data yang dilakukan dalam penelitian ini adalah:

- Studi Pustaka

Pengumpulan data dengan menggunakan atau mengumpulkan sumber-sumber tertulis, dengan cara membaca, mempelajari dan mencatat hal-hal penting yang berhubungan dengan masalah yang sedang dibahas guna memperoleh gambaran secara teoritis yang dapat menunjang pada penyusunan Skripsi.

- Wawancara

Pengumpulan data dengan cara melakukan komunikasi dan wawancara secara langsung dengan Ahli Gizi mengenai kriteria makanan yang menunjang diet.

\section{B. Metode Pengembangan Sistem Pendukung Keputusan}

Model proses yang digunakan dalam pengembangan perangkat lunak ini adalah Model Waterfall, digunakan pendekatan berbasis sekuential linier, alasan menggunakan model ini karena model ini mengusulkan sebuah pendekatan kepada pengembangan software yang sistematik dan sekuensial yang mulai pada tingkatan dan kemajuan sistem pada seluruh analisis, desain/perancangan, kode, pengujian/tes dan pemeliharaan. Berikut merupakan proses skema dalam model proses sekuential linier/waterfall[6]:

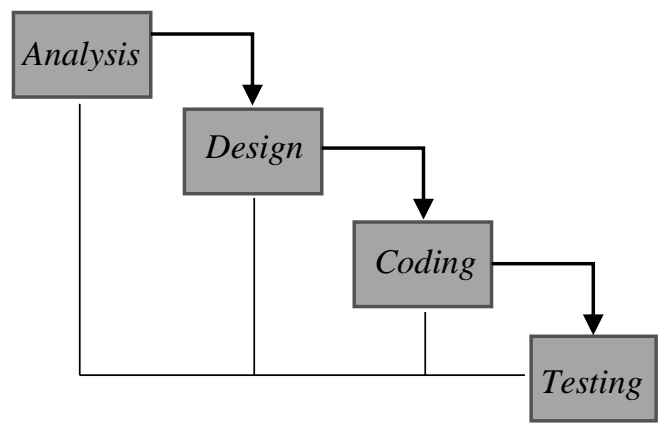

Gambar 1 Sekuensial Linier/Waterfall.

(Sumber: Tanti Kristanti and Niluh Gede Redita A.K. 2012)
Model sekuential linier/waterfall dalam skripsi ini adalah sebagai berikut:

1) Analysis

Analisa terhadap kebutuhan sistem analis terhadap permasalahan dan mendefiniskan model penyelesaian, termasuk dalam proses ini adalah melakukan analisis terhadap spesifikasi perangkat lunak yang akan dibangun. Pengumpulan data dalam skripsi ini menggunakan wawancara dan studi pustaka, guna mengambil informasi yang dibutuhkan sehingga akan tercipta sebuah aplikasi yang bisa melakukan tugas-tugas yang diinginkan oleh user.

2) Design

Design perangkat lunak berkaitan rancangan database, rancangan interface dan dimodelkan dalam arsitektur sistem aplikasi. Proses desain menerjemahkan syarat/kebutuhan ke dalam sebuah representasi perangkat.

\section{3) Coding}

Tahap penerjemahan desain sistem dalam bentuk bahasa-bahasa pemrograman tertentu dengan memasukkan algoritma-algoritma dalam membangun aplikasi sistem pendukung keputusan rekomendasi makanan khas sulawesi utara yang menunjang diet. Pada penelitian ini, bahasa pemrograman yang digunakan yaitu $P H P$.

4) Testing

Setelah coding, tahap perangkat lunak di uji untuk setiap kesalahan dan kegagalan untuk diperbaiki agar layak digunakan dengan metode black box untuk memastikan bahwa perangkat lunak yang dibuat sesuai dengandesain dan dapat digunakan oleh user sehingga mendapatkan hasil yang dibutuhkan.

\section{Data Makanan Khas Sulawesi Utara}

Data makanan khas sulawesi utara dan komposisi makanan diperoleh dari penelitian sebelumnya oleh Muhammad Iqbal Kaplale (2016), kriteria yang di ambil yaitu berupa kandungan makanan yaitu Protein, Karbohidrat dan Lemak, data makanan yang di ambil dengan jumlah 14 jenis makanan, daftar makanan beserta kandungan dapat dilihat pada tabel I[3].

Tabel I

KANDUNGAN GIZI MAKANAN.

(Sumber: Kaplale. 2016)

\begin{tabular}{|c|l|l|l|l|}
\hline No & Nama Makanan & Protein & $\begin{array}{c}\text { Karbo } \\
\text { hidrat }\end{array}$ & Lemak \\
\hline 1 & Tinutuan (Bubur & 11.53 & 85.08 & 3.39 \\
\hline
\end{tabular}




\begin{tabular}{|c|l|l|l|l|}
\hline & Manado) & & & \\
\hline 2 & Klapatart & 10.67 & 69.62 & 19.71 \\
\hline 3 & Saut & 45 & 27.37 & 27.63 \\
\hline 4 & Nasi Jaha & 7.78 & 90.85 & 1.37 \\
\hline 5 & Tinoransak & 42.68 & 21.01 & 36.31 \\
\hline 6 & Kawok (Tikus) & 18.17 & 63.66 & 18.17 \\
\hline 7 & $\begin{array}{l}\text { Paniki } \\
\text { (Kelelawar) }\end{array}$ & 13.16 & 42.34 & 44.5 \\
\hline 8 & $\begin{array}{l}\text { RW (Daging } \\
\text { Anjing) }\end{array}$ & 53.08 & 28.77 & 18.15 \\
\hline 9 & Woku Blanga & 57 & 12.72 & 30.28 \\
\hline 10 & Sate Kolombi & 8.85 & 86.04 & 5.11 \\
\hline 11 & Mie Cakalang & 23.95 & 66.82 & 9.23 \\
\hline 12 & Rica Roa & 15.72 & 44.47 & 39.81 \\
\hline 13 & Ragey & 57.43 & 2.13 & 40.44 \\
\hline 14 & Patola & 14.27 & 62.59 & 23.14 \\
\hline
\end{tabular}

Tabel II

BOBOT KRITERIA NORMAL

\begin{tabular}{|l|l|}
\hline Protein & $20 \%$ \\
\hline Karbohidrat & $60 \%$ \\
\hline Lemak & $20 \%$ \\
\hline
\end{tabular}

Tabel III

BOBOT KRITERIA DIET

\begin{tabular}{|l|l|}
\hline Protein & $40 \%$ \\
\hline Karbohidrat & $50 \%$ \\
\hline Lemak & $10 \%$ \\
\hline
\end{tabular}

Data bobot kriteria merupakan bobot penilaian yang akan di gunakan saat perhitungan pada sistem pendukung keputusan menggunakan metode $A H P$, bobot kriteria yang didapat dari hasil pengumpulan data dengan melalukan wawancara kepada ahli gizi, data bobot yang di ambil untuk orang dewasa umur 10 tahun dan seterusnya, berbadan sehat dan tidak memiliki riwayat penyakit.

Pada Tabel II merupakan bobot kriteria untuk asupan gizi normal, untuk menjaga agar badan tetap ideal.

Pada Tabel III merupakan bobot kriteria untuk asupan gizi orang yang akan diet untuk penurunan berat badan, kandungan karbohidrat dan lemak yang lebih rendah, dapat menurunkan berat badan bagi yang melakukan diet.
D. Rancangan Basis Data

Basis data merupakan salah satu komponen yang penting karena berfungsi sebagai basis penyedia data baik bagi pengguna maupun sistem. Penekanan dari data yang disimpan secara temporary merupakan data yang diperoleh dariperhitungan-perhitungan pada matrik perbandingan, pembobotan, dan prioritas.

Tabel IV

TABEL KRITERIA

\begin{tabular}{|c|l|l|l|}
\hline No & \multicolumn{1}{|c|}{ Field } & \multicolumn{1}{c|}{ Type } & \multirow{2}{*}{ Primary key } \\
\hline 1 & Id_kriteria & Varchar(255) & Priar \\
\hline 2 & Nama_kriteria & Varchar(255) & \\
\hline 3 & Created_at & Timestamp & \\
\hline 4 & Update_at & Timestamp & \\
\hline
\end{tabular}

Tabel V

TABEL MATRIK KRITERIA

\begin{tabular}{|c|l|l|l|}
\hline No & \multicolumn{1}{|c|}{ Field } & \multicolumn{1}{c|}{ Type } & \\
\hline 1 & Id & Int(10) & Primary key \\
\hline 2 & Id_kriteria & Varchar(255) & \\
\hline 3 & Id_bandingan & Varchar(255) & \\
\hline 4 & Nilai & Double(8,2) & \\
\hline 5 & Created_at & Timestamp & \\
\hline 6 & Update_at & Timestamp & \\
\hline
\end{tabular}

Tabel VI

Tabel Normalisasi Kriteria

\begin{tabular}{|c|l|l|l|}
\hline No & \multicolumn{1}{|c|}{ Field } & \multicolumn{1}{c|}{ Type } & \multirow{2}{*}{ Primary key } \\
\hline 1 & Id & Int(10) & \\
\hline 2 & Id_kriteria & Varchar(255) & \\
\hline 3 & Id_bandingan & Varchar(255) & \\
\hline 4 & Nilai & Double(8,2) & \\
\hline 5 & Created_at & Timestamp & \\
\hline 6 & Update_at & Timestamp & \\
\hline
\end{tabular}

Tabel VII

TABEL MAKANAN

\begin{tabular}{|c|l|l|l|}
\hline No & \multicolumn{1}{|c|}{ Field } & \multicolumn{1}{c|}{ Type } & \multirow{2}{*}{ Primary key } \\
\hline 1 & Id_makanan & Int(10) & \\
\hline 2 & Nama_makanan & Varchar(255) & \\
\hline 3 & Tipe & Varchar(255) & \\
\hline 4 & Asal_makanan & Varchar(255) & \\
\hline 5 & Created_at & Timestamp & \\
\hline 6 & Update_at & Timestamp & \\
\hline
\end{tabular}


Tabel VIII

TABEL BOBOT KRITERIA

\begin{tabular}{|c|l|l|l|}
\hline No & \multicolumn{1}{|c|}{ Field } & \multicolumn{1}{c|}{ Type } & \\
\hline 1 & id_kriteria & varchar(255) & Primary key \\
\hline 2 & nama_kriteria & varchar(255) & \\
\hline 3 & bobot & double $(8,2)$ & \\
\hline 4 & created_at & timestamp & \\
\hline 5 & update_at & timestamp & \\
\hline
\end{tabular}

Tabel IX TABEL KONSISTENSI

\begin{tabular}{|c|l|l|}
\hline No & \multicolumn{1}{|c|}{ Field } & \multicolumn{1}{c|}{ Type } \\
\hline 1 & Cr & Double $(8,2)$ \\
\hline 2 & Created_at & Timestamp \\
\hline 3 & Update_at & Timestamp \\
\hline
\end{tabular}

Tabel X

TABEL EVALUASI

\begin{tabular}{|c|l|l|l|}
\hline No & \multicolumn{1}{|c|}{ Field } & \multicolumn{1}{c|}{ Type } & \multirow{2}{*}{ Primary key } \\
\hline 1 & Id_makanan & Int(10) & \\
\hline 2 & Id_kriteria & Varchar(255) & \\
\hline 3 & nilai & Int(11) & \\
\hline 4 & Created_at & Timestamp & \\
\hline 5 & Update_at & Timestamp & \\
\hline
\end{tabular}

Tabel XI

TABEL HASIL EVALUASI

\begin{tabular}{|c|l|l|l|}
\hline No & \multicolumn{1}{|c|}{ Field } & \multicolumn{1}{|c|}{ Type } & \multirow{2}{*}{ Primary key } \\
\hline 1 & Id_makanan & Int $(10)$ & \\
\hline 2 & Total_nilai & Double $(8,2)$ & \\
\hline 3 & Created_at & Timestamp & \\
\hline 4 & Update_at & Timestamp & \\
\hline
\end{tabular}

\section{E. Use Case Diagram}

Pengguna Sistem Pendukung Keputusan Rekomendasi Makanan khas Sulawesi Utara yang Menunjang Diet yang di gambarkan dengan aktor user. Pada sistem ini aktivitias user bisa mengakses semua yang ada pada sistem, dan dapat menambahkan data makanan, edit makanan, hapus makanan, edit kriteria, pembobotan dan melihat hasil akhir. Pada bagian kriteria hanya dapat mengubah data, jika ada kesalahan dalam penulisan kata. Bagian pembobotan, disini user melakukan pembobotan dengan perbandingan berpasangan, memberikan grade/bobot pada kriteria, sehingga akan menghasilkan nilai Consistency Ratio. Dalam perangkingan, user dapat mengevaluasi data makanan/memberikan nilai pada makanan yang akan dilakukan proses perhitungan menggunakan metode
$A H P$, dan akan menghasilkan rangking makanan, seperti pada Gambar 2.

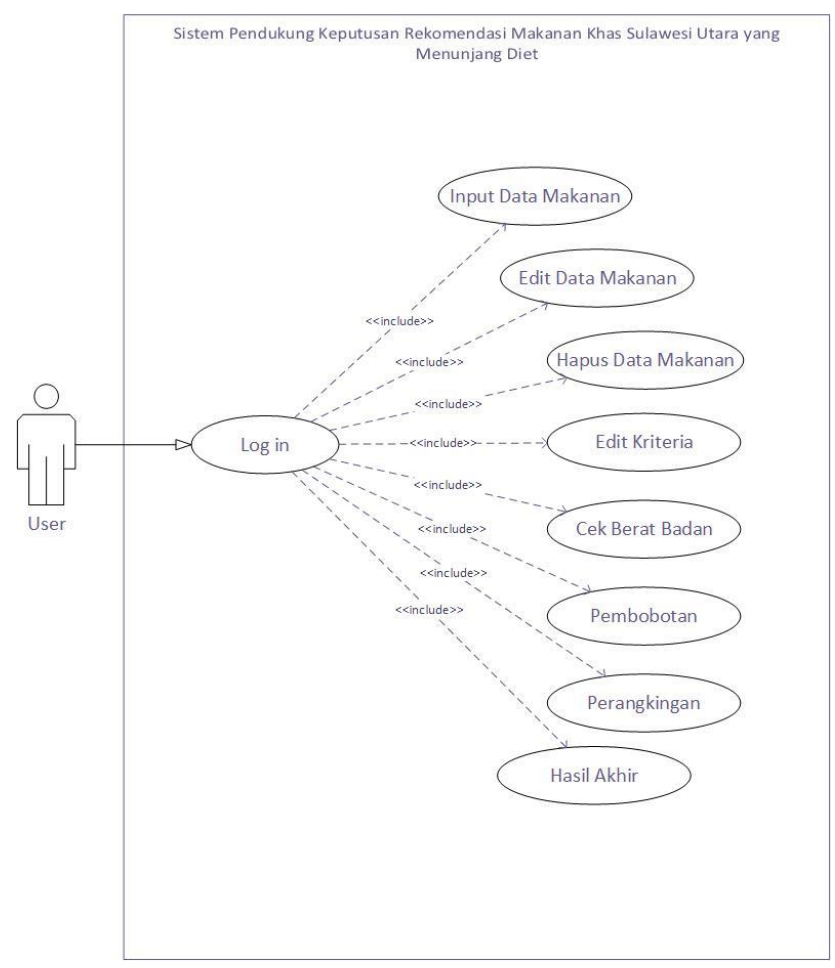

Gambar 2 Use Case Diagram

F. Rancangan Storyboard

\begin{tabular}{|c|c|}
\hline \multicolumn{2}{|r|}{ Header } \\
\hline $\begin{array}{l}\text { Menu : } \\
\text { Beranda } \\
\text { Data Makanan } \\
\text { Kriteria } \\
\text { Bobot } \\
\text { Perangkingan } \\
\text { Hasil Akhir } \\
\text { Info }\end{array}$ & $\begin{array}{c}\text { Gambaran Umum } \\
\text { Sistem Pendukung Keputusan } \\
\text { dengan Metode Analytical } \\
\text { Hierarchy Process }\end{array}$ \\
\hline & Footer \\
\hline
\end{tabular}

Gambar 3Storyboard halaman awal 
Interface design atau yang biasa disebut rancangan antarmuka berfungsi untuk memudahkan pengguna berinteraksi dengan sistem. Rancangan antarmuka yang baik dapat membuat pengguna mudah mengerti dan nyaman dalam penggunaan perangkat lunak tersebut. Berikut rancangan antar muka (interfac edesign) dari Sistem Pendukung Keputusan Rekomendasi Makanan Khas Sulawesi Utara yang Menunjang Diet melalui storyboard:

Pada Gambar 3, bagian atas merupakan header aplikasi, dan bagian kiri terdapat menu yang berisikan link halaman, dan pa bagian isi merupakan gambaran umum dari Sistem Pendukung Keputusan dengan metode Analytical Hierarchy Process, serta pada bagian bawah adalah footer.

\section{IV.HASIL DAN PEMBAHASAN}

\section{A. Pembahasan Aplikasi Sistem Pendukung Keputusan}

Gambar 4 merupakan tampilan utama sistem pendukung keputusan yang terdiri dari enam menu, yaitu beranda, data makanan, kriteria, bobot dan perangkingan, pada halaman ini hanya berisikan informasi penjelasan tentang sistem pendukung keputusan metode $A H P$.

Gambar 5 merupakan halaman login,berfungsi untuk membatasi akses halaman-halaman tertentu yang disediakan pada web tersebut. Hanya user tertentu saja yang diijinkan mengakses layanan-layanan khusus tersebut, seperti halaman data, untuk menambah data, mengubah data, maupun menghapus data, dan juga pada halaman kriteria, pembobotan sampai perangkingan.

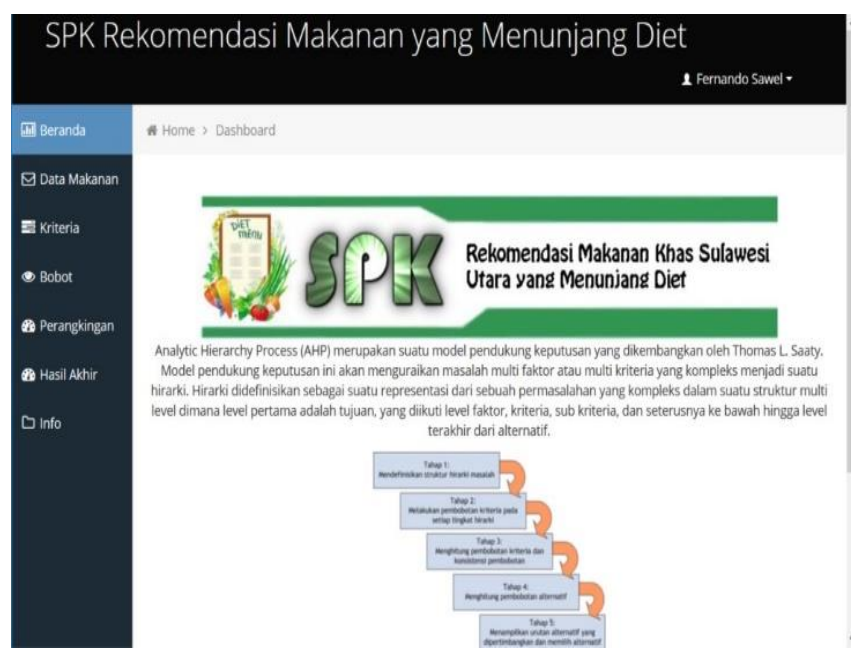

Gambar 4 Halaman Beranda

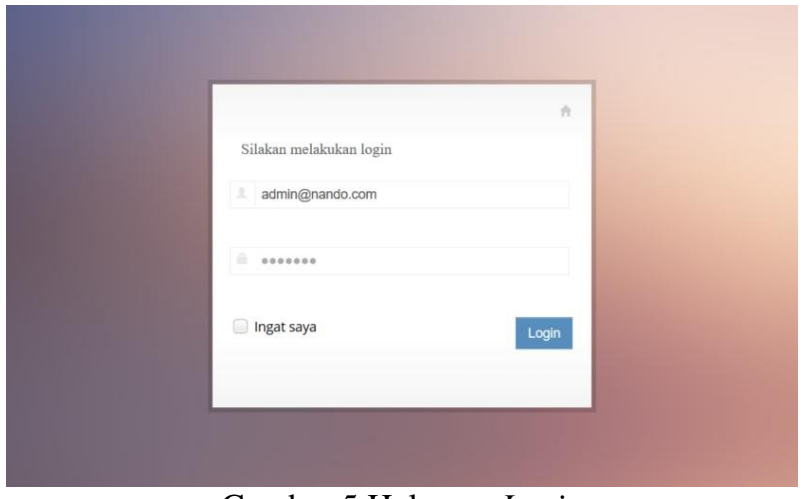

Gambar 5 Halaman Login

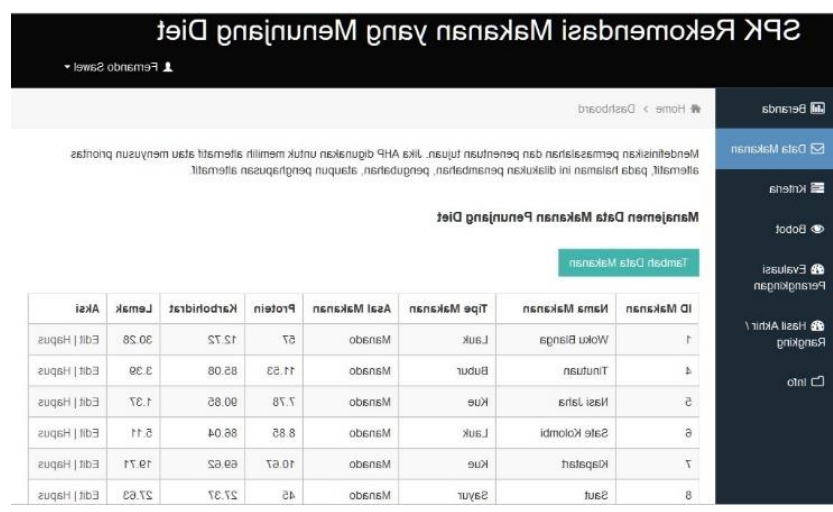

Gambar 6 Halaman Data Makanan

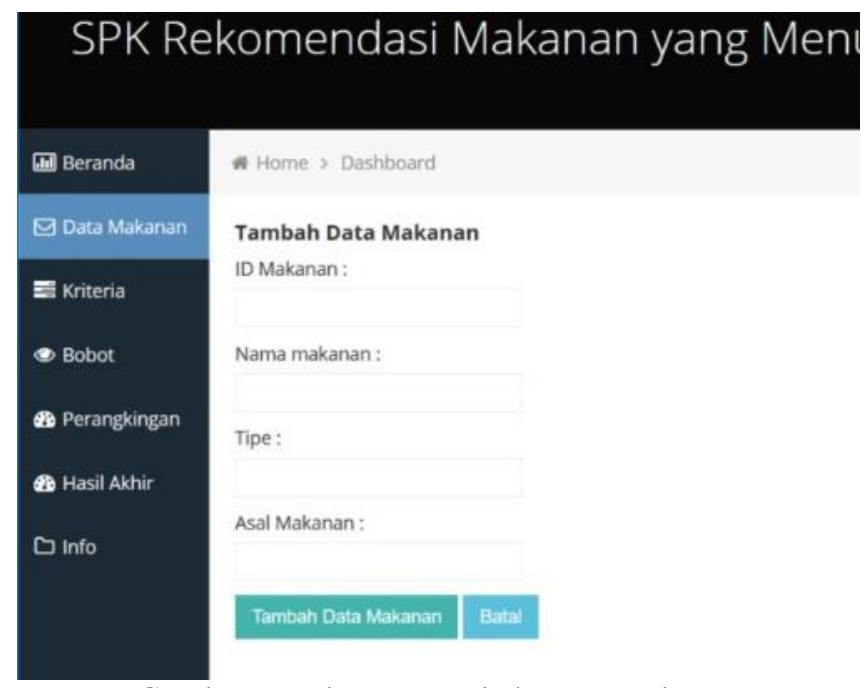

Gambar 7 Halaman Tambah Data Makanan 


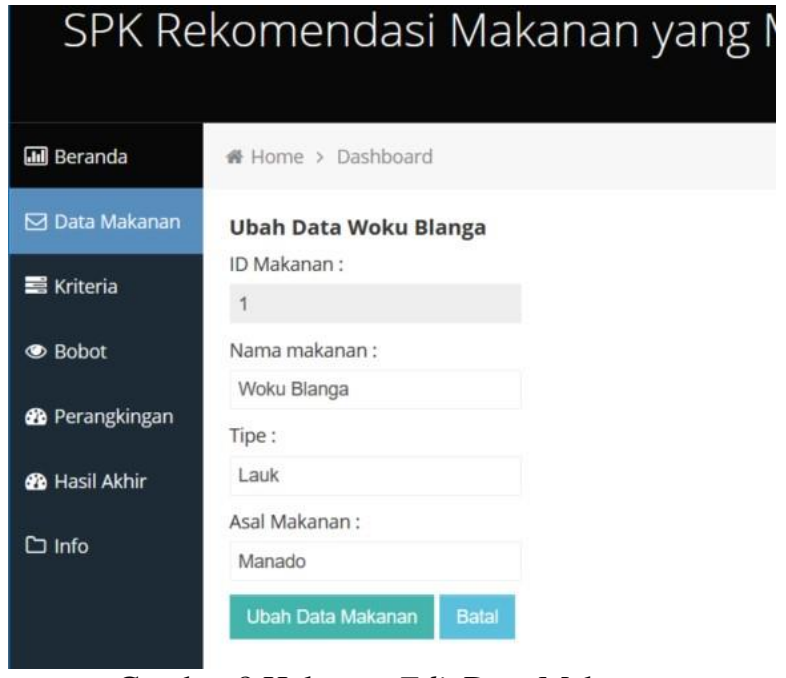

Gambar 8 Halaman Edit Data Makanan

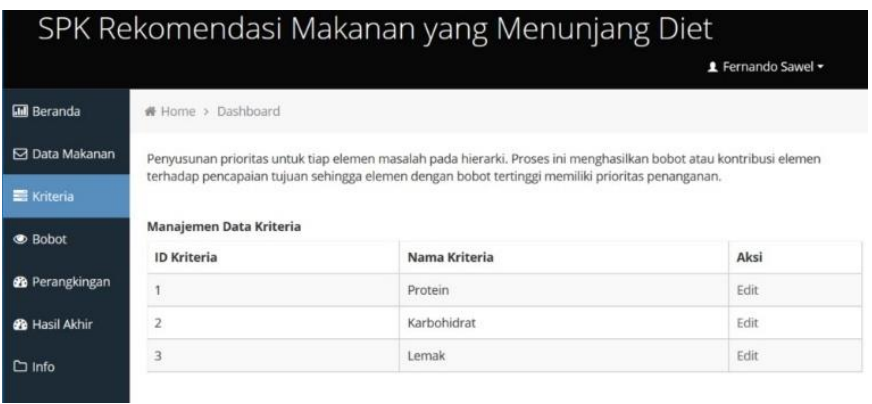

Gambar 9 Halaman Kriteri

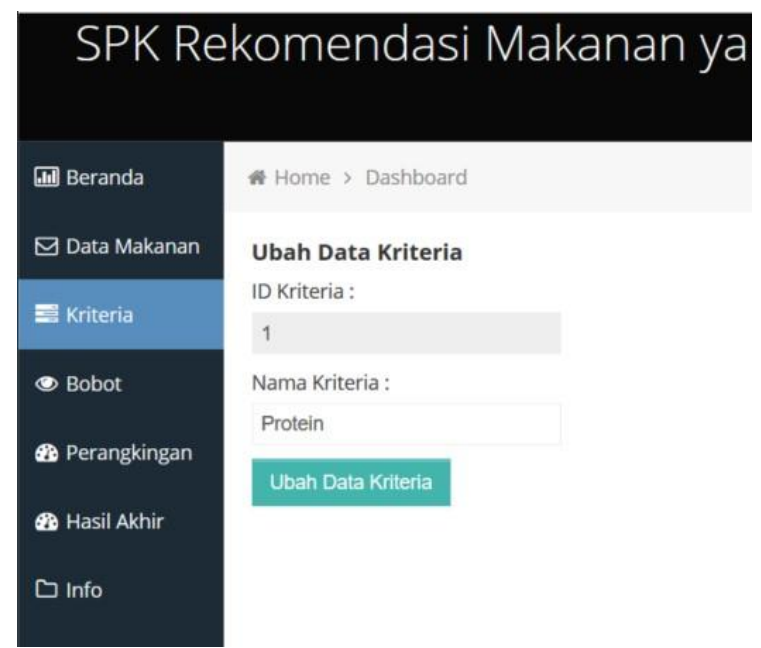

Gambar 10 Halaman Edit Data Kriteria

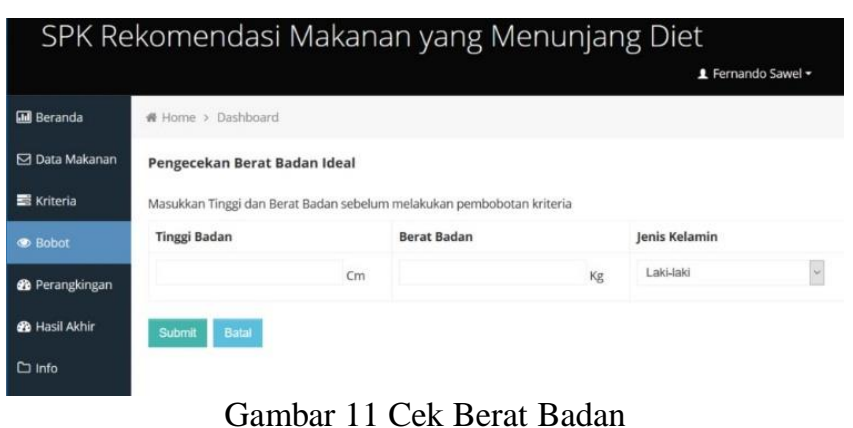

Gambar 6 berfungsi untuk melihat data makanan yang sudah di masukkan, pada halaman ini pengguna bebas menambahkan data makanan, mengedit makanan yang sebelumnya sudah di tambahkan dan juga menghapus data.

Gambar 7 merupakan halaman untuk menambahkan data makanan baru untuk di evaluasi, terdapat beberapa field untuk meginput data makanan.

Gambar 8merpukana halaman edit data makanan, berfungsi untuk mengubah data makanan jika adadata yang salah atau kurang lengkap.

Gambar 9untuk melihat data kriteria yang sudah di masukkan ke dalam sistem, pengguna dapat mengedit data kriteria, pada halaman ini tidak ada fitur penambahan kriteria, karena pada proses perhitungan nanti akan menggunakan matriks perbandingan $3 \times 3$, jadi pada halaman ini hanya menampilkan 3 kriteria.

Gambar 10merupakan halaman edit kriteria untuk mengubah data kriteria, pada halaman ini $I D$ Kriteria tidak dapat di ubah, hanya nama yang dapat di ubah.
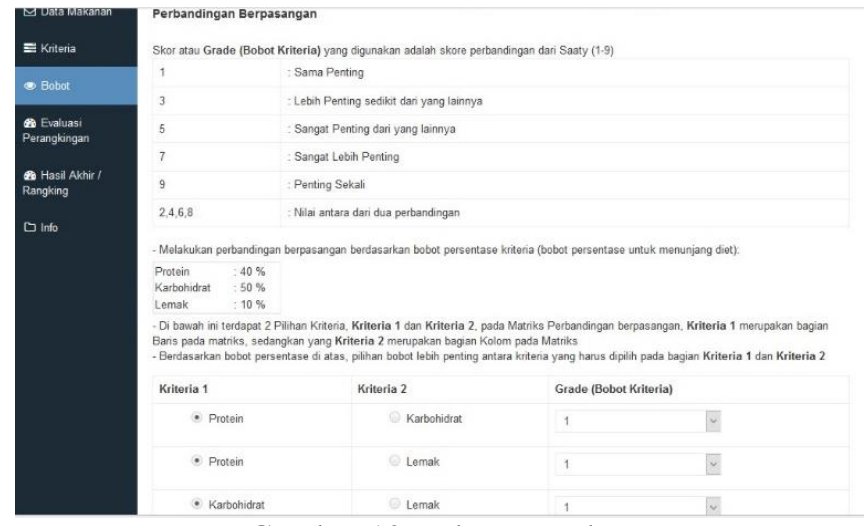

Gambar 12 Halaman Bobot 


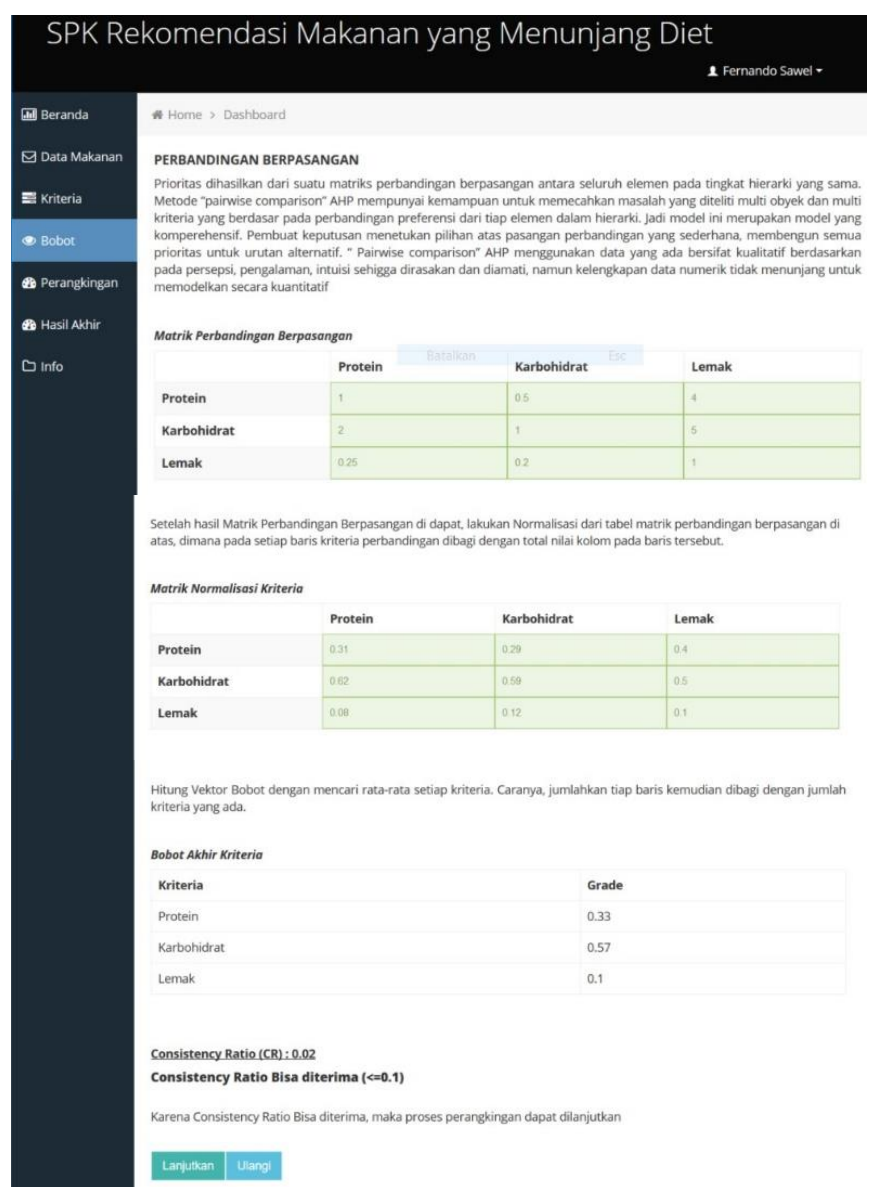

Gambar 13 Hasil Pembobotan Kriteria

Gambar 12berfungsi untuk melakukan perbandingan berpasangan antara kriteria dengan kriteria lainnya, memberikan nilai bobot dari 1 - 9 berdasarkan score perbandingan dari Saaty, namun sebelum melakkan pembobotan, pada Gambar 11 user harus melakukan pengecekan berat badan. jika berat badan termasuk kurus, maka user tidak dapat melakukan pembobotan, jika berat badan gemuk, user dapat melanjutkan pembobotan, dan melakukan pembobotan dari setiap kriteria, setelah itu akan di lanjutkan dengan proses perhitungan $A H P$.

Setelah pemberian bobot pada masing - masing kriteria, klik tombol submit untuk melakukan proses perhitungan perbandingan berpasangan, dan akan menghasilkantabel perbandingan antar kriteria, seperti pada Gambar 13, tabel normalisasi kriteria, bobo akhir kriteria dan akan mendapatkan nilai Consistenscy Ratio $(C R)$, jika nilai $C R>0.1$ maka tidak rasio, dan harus di ulangi pembobotan, jika nilai $C R<0.1$ maka nilai $C R$ rasio, dan bisa dilanjutkan untuk mengevaluasi data makanan,

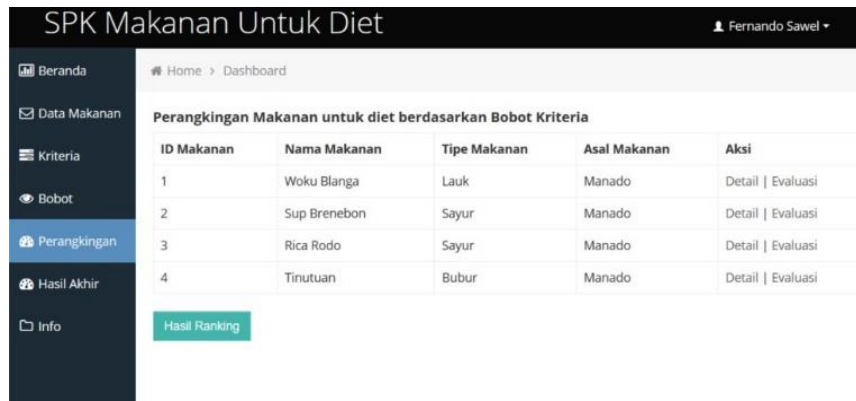

Gambar 14 Halaman Evaluasi Makanan

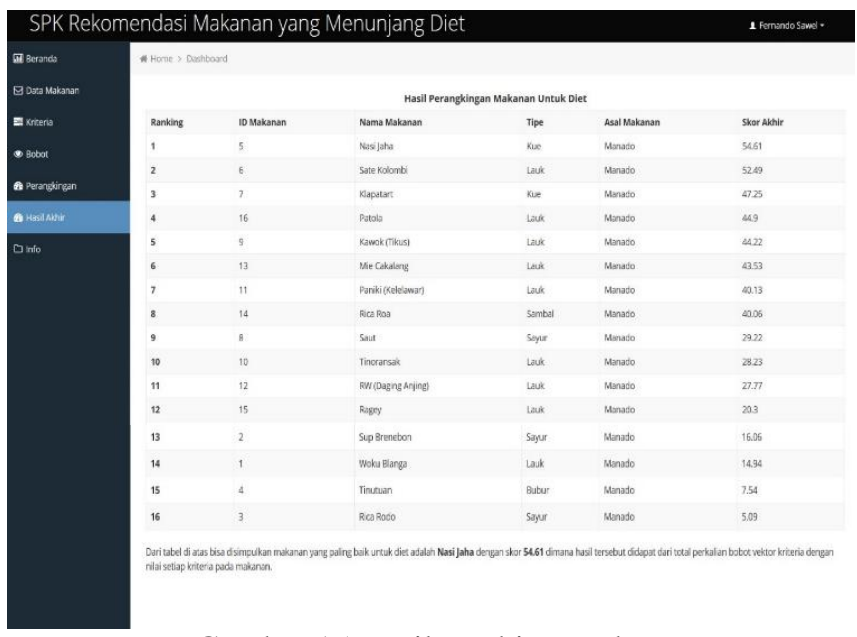

Gambar 15 Hasil Ranking Makanan

Pada tahap selanjutnya, kita akan mengevaluasi data makanangambar 14, dengan mengklik evaluasi setiap makanan, dan melakukan pemberian nilai makanan berdasarkan data kandungan pada makanan yang sudah di dapat dari rumah sakit, seperti dilihat pada Gambar 14.

Setelah semua data sudah di evaluasi, klik tombol hasil rangking untuk melihat ranking makanan, seperti pada Gambar 15.

\section{B. Hasil Perhitungan AHP Manual}

- Membuat matriks perbandingan berpasangan yang menggambarkan kontribusi relatif atau pengaruh setiap elemen terhadap masing-masing kriteria dengan kriteria lain, skala 1 sampai 9 adalah skala terbaik dalam membandingkan elemen, dapat dilihat pada tabel XII.

Tabel XIII

SKALA PERBANDINGAN BERPASANGAN

\begin{tabular}{|l|c|c|c|} 
& Protein & Karbohidrat & Lemak \\
\hline Protein & 1 & $1 / 2$ & 4 \\
\hline Karbohidrat & 2 & 1 & 5 \\
\hline
\end{tabular}




\section{Lemak}

$1 / 4$

$1 / 5$

1

- Skala perbandingan pada tabel XIII, beradasarkan data persentase bobot dari setiap Kriteria yang diperoleh dari hasil Wawancara dengan Ahli Gizi dengan kategori umur dewasa 10 Tahun - dst..., Data persentase dari ketiga kriteria dapat dilihat pada tabel III.

- Mengubah nilai perbandingan menjadi bentuk desimal, dapat dilihat pada tabel 18.

Tabel XIV

MATRIK PERBANDINGAN BERPASANGAN

\begin{tabular}{|l|c|c|c|} 
& Protein & Karbohidrat & Lemak \\
\hline Protein & 1 & 0.5 & 4 \\
\hline Karbohidrat & 2 & 1 & 5 \\
\hline Lemak & 0.25 & 0.2 & 1 \\
\hline
\end{tabular}

- Menjumlahkan nilai-nilai dari setiap kolom pada matriks, dapat dilihat pada tabel XIV.

Tabel XV

PENJUMLAHAN KOLOM

\begin{tabular}{|l|c|c|c|} 
& Protein & Karbohidrat & Lemak \\
\hline Protein & 1 & 0.5 & 4 \\
\hline Karbohidrat & 2 & 1 & 5 \\
\hline Lemak & 0.25 & 0.2 & 1 \\
\hline \multicolumn{1}{|c|}{ Jumlah } & 3.25 & 1.7 & 10 \\
\hline
\end{tabular}

- Membagi setiap nilai dari kolom dengan total kolom yang bersangkutan untuk memperoleh normalisasi matriks, kemudian menjumlahkan nilai-nilai dari baris dan membaginya dengan jumlah elemen (n) atau kriteria untuk mendapatkan nilai prioritas (TPV). Penjumlahan baris dapat dilihat pada tabel XV.

Tabel XVI

PENJUMLAHAN BARIS DAN PRIORITY VEKTOR

\begin{tabular}{|l|c|c|c|c|c|} 
& Protein & $\begin{array}{c}\text { Karbo } \\
\text { hidrat }\end{array}$ & Lemak & Jumlah & $\boldsymbol{T P V}$ \\
\hline Protein & 0.31 & 0.29 & 0.4 & 1 & 0.33 \\
\hline $\begin{array}{l}\text { Karbohi } \\
\text { drat }\end{array}$ & 0.62 & 0.59 & 0.5 & 1.71 & 0.57 \\
\hline Lemak & 0.08 & 0.12 & 0.1 & 0.3 & 0.1 \\
\hline
\end{tabular}

- Memeriksa konsistensi (Consistency Ratio atau CR) matriks perbandingan suatu kriteria. Matriks Perbandingan dinyatakan konsisten jika nilai $C R<0.1$, tetapi nilai $C R>0.1$ maka pertimbangan yang di buat perlu di perbaiki dan diteliti kembali.

- Mencari $\lambda$ maks

$(3.25 \times 0.33)+(1.7 \times 0.57)+(10 \times 0.1)$

$=1.07+0.96+1$

$=3.03 \leftarrow \lambda$ maks

- Setelah mendapatkan $\lambda$ maks, selanjutnya mencari nilai Consistency Index $(C I)$

$C I=\lambda$ maks $-\mathbf{n} / \mathbf{n}-\mathbf{1}$

$=3.03-3 / 3-1$

$=0.01$

- Mencari nilai Consistency Ratio (CR) dengan rumus dibawah ini.

$C R=C I / R I$

$=0.02 \leftarrow C R$

Nilai $C R<0.1$ Matriks Perbandingan Konsisten.

- Pada tahap selanjutnya adalah perangkingan dari alternatif, yaitu rangking berupa data makanan yang di peroleh, dengan melakukan evaluasi nilai makanan berdasarkan 3 kandungan, yaitu protein, karbohidrat dan lemak dari tiap - tiap alternatif (makanan), dapat dilihat pada tabel XVII.

Tabel XVII

SKOR KANDUNGAN GIZI

\begin{tabular}{|r|l|l|l|l|}
\hline No & Nama Makanan & Protein & $\begin{array}{l}\text { Karbo } \\
\text { hidrat }\end{array}$ & Lemak \\
\hline 1 & $\begin{array}{l}\text { Tinutuan (Bubur } \\
\text { Manado) }\end{array}$ & 11.53 & 85.08 & 3.39 \\
\hline 2 & Klapatart & 10.67 & 69.62 & 19.71 \\
\hline 3 & Saut & 45 & 27.37 & 27.63 \\
\hline 4 & Nasi Jaha & 7.78 & 90.85 & 1.37 \\
\hline 5 & Tinoransak & 42.68 & 21.01 & 36.31 \\
\hline 6 & Kawok (Tikus) & 18.17 & 63.66 & 18.17 \\
\hline 7 & $\begin{array}{l}\text { Paniki } \\
\text { (Kelelawar) }\end{array}$ & 13.16 & 42.34 & 44.5 \\
\hline 8 & $\begin{array}{l}\text { RW (Daging } \\
\text { Anjing) }\end{array}$ & 53.08 & 28.77 & 18.15 \\
\hline 9 & Woku Blanga & 57 & 12.72 & 30.28 \\
\hline 10 & Sate Kolombi & 8.85 & 86.04 & 5.11 \\
\hline 11 & Mie Cakalang & 23.95 & 66.82 & 9.23 \\
\hline 12 & Rica Roa & 15.72 & 44.47 & 39.81 \\
\hline 13 & Ragey & 57.43 & 2.13 & 40.44 \\
\hline 14 & Patola & 14.27 & 62.59 & 23.14 \\
\hline
\end{tabular}

- Rumus untuk perangkingan sebagai berikut : 
$(T P V$ Protein x Skor Kandungan Gizi Protein) $+(T P V$ Karbohidrat x Skor Kandungan Gizi Karbohidrat) + (TPV Lemak x Skor Kandungan Gizi Lemak) dst..., dan hasilnya dapat dilihat pada tabel XVIII.

\section{Tabel XVIII}

HASIL PENJUMLAHAN

\begin{tabular}{|l|l|}
\hline Tinutuan (Bubur Manado) & 52.64 \\
\hline Klapatart & 45.18 \\
\hline Saut & 33.21 \\
\hline Nasi Jaha & 54.49 \\
\hline Tinoransak & 29.69 \\
\hline Kawok (Tikus) & 44.1 \\
\hline Paniki (Kelelawar) & 32.93 \\
\hline RW (Daging Anjing) & 35.73 \\
\hline Woku Blanga & 29.09 \\
\hline Sate Kolombi & 52.47 \\
\hline Mie Cakalang & 46.91 \\
\hline Rica Roa & 34.52 \\
\hline Ragey & 24.21 \\
\hline Patola & 42.7 \\
\hline
\end{tabular}

- Setelah hasil yang didapat dari penjumlahan $(T P V$ Protein $\mathrm{x}$ Protein $)+(T P V$ Karbohidrat $\mathrm{x}$ Karbohidrat $)+$ (TPV Lemak x Lemak) dst..., selanjutnya melakukan perangkingan.

\section{Tabel XIX} HASIL RANGKING

\begin{tabular}{|c|l|c|}
\hline Ranking & Nama Makanan & Skor Akhir \\
\hline 1 & Nasi Jaha & 54.49 \\
\hline 2 & Tinutuan & 52.64 \\
\hline 3 & Sate Kolombi & 52.47 \\
\hline 4 & Mie Cakalang & 46.91 \\
\hline 5 & Klapatart & 45.18 \\
\hline 6 & Kawok (Tikus) & 44.1 \\
\hline 7 & Patola & 42.7 \\
\hline 8 & RW (Daging Anjing) & 35.73 \\
\hline 9 & Rica Roa & 34.52 \\
\hline 10 & Saut & 33.21 \\
\hline 11 & Paniki & 32.93 \\
\hline 12 & Tinoransak & 29.69 \\
\hline 13 & Woku Blanga & 29.09 \\
\hline 14 & Ragey & 24.21 \\
\hline
\end{tabular}

Dari tabel XIX, bisa disimpulkan makanan yang paling baik untuk diet adalah Nasi Jaha dengan skor 54.49 dimana hasil tersebut didapat dari total perkalian bobot vektor kriteria dengan nilai setiap kriteria pada makanan

\section{Pengujian Sistem}

Aplikasi sistem pendukung keputusan rekomendasi makanan khas sulawesi utara yang menunjang diet yang telah dibuat diuji dengan menggunakan metode black box. Pengujian yang dilakukan hanya mengamati hasil eksekusi melalui data uji dan memeriksa fungsional dari perangkat lunak. Pengujian black box aplikasi dapat dilihat seperti pada tabel XX.

Tabel XX

PENGUJIAN BLACK BOX

\begin{tabular}{|c|c|c|c|c|}
\hline $\begin{array}{l}\mathrm{N} \\
\mathrm{o}\end{array}$ & $\begin{array}{l}\text { Kasus/Form } \\
\text { Uji }\end{array}$ & Skenario Uji & $\begin{array}{l}\text { Hasil yang } \\
\text { Diharapkan }\end{array}$ & $\begin{array}{l}\text { Hasil } \\
\text { Penguji } \\
\text { an }\end{array}$ \\
\hline \multirow{4}{*}{1} & \multirow{4}{*}{$\begin{array}{l}\text { Mengecek } \\
\text { Menu } \\
\text { Makanan }\end{array}$} & $\begin{array}{l}\text { - Membuka } \\
\text { menu } \\
\text { makanan }\end{array}$ & $\begin{array}{l}\text { - Muncul } \\
\text { Halaman } \\
\text { Makanan }\end{array}$ & Sukses \\
\hline & & $\begin{array}{l}\text { - Menambah } \\
\text { data } \\
\text { makanan }\end{array}$ & $\begin{array}{l}\text { - Data } \\
\text { Makanan } \\
\text { dapat di } \\
\text { tambah }\end{array}$ & Sukses \\
\hline & & $\begin{array}{l}\text { - Merubah } \\
\text { data } \\
\text { makanan }\end{array}$ & $\begin{array}{l}\text {-Data } \\
\text { makanan } \\
\text { dapat di } \\
\text { rubah }\end{array}$ & Sukses \\
\hline & & $\begin{array}{l}\text { - Menghapus } \\
\text { Data } \\
\text { makanan }\end{array}$ & $\begin{array}{l}\text {-Data } \\
\text { makanan } \\
\text { dapat di } \\
\text { hapus }\end{array}$ & Sukses \\
\hline \multirow[b]{2}{*}{2} & \multirow{2}{*}{$\begin{array}{l}\text { Mengecek } \\
\text { Menu } \\
\text { Kriteria }\end{array}$} & $\begin{array}{l}\text { - Membuka } \\
\text { menu } \\
\text { kriteria }\end{array}$ & $\begin{array}{l}\text { - Muncul } \\
\text { halaman } \\
\text { kriteria }\end{array}$ & Sukses \\
\hline & & $\begin{array}{l}\text { - Merubah } \\
\text { data kriteria }\end{array}$ & $\begin{array}{l}\text {-Data } \\
\text { makanan } \\
\text { dapat di } \\
\text { rubah }\end{array}$ & Sukses \\
\hline \multirow{3}{*}{3} & \multirow{3}{*}{$\begin{array}{l}\text { Mengecek } \\
\text { Menu Bobot }\end{array}$} & $\begin{array}{l}\text { - Membuka } \\
\text { menu bobot }\end{array}$ & $\begin{array}{l}\text { - Muncul } \\
\text { Halaman } \\
\text { bobot }\end{array}$ & Sukses \\
\hline & & $\begin{array}{l}\text { - Cek berat } \\
\text { badan }\end{array}$ & $\begin{array}{l}\text { - Muncul } \\
\text { halaman } \\
\text { pembobotan }\end{array}$ & Sukses \\
\hline & & $\begin{array}{l}- \\
\text { Pembobotan } \\
\text { Kriteria }\end{array}$ & $\begin{array}{l}\text { - Muncul } \\
\text { Halaman } \\
\text { Matrik }\end{array}$ & Sukses \\
\hline 4 & $\begin{array}{l}\text { Mengecek } \\
\text { Menu }\end{array}$ & $\begin{array}{l}\text { - Membuka } \\
\text { menu }\end{array}$ & $\begin{array}{l}\text { - Muncul } \\
\text { Halaman }\end{array}$ & Sukses \\
\hline
\end{tabular}




\begin{tabular}{|l|l|l|l|l|}
\hline \multirow{2}{*}{$\begin{array}{l}\text { Perangkinga } \\
\mathrm{n}\end{array}$} & $\begin{array}{l}\text { Perangkinga } \\
\mathrm{n}\end{array}$ & $\begin{array}{l}\text { perangkinga } \\
\mathrm{n}\end{array}$ & \\
\cline { 3 - 5 } & $\begin{array}{l}\text { - Melihat } \\
\text { detail } \\
\text { makanan }\end{array}$ & $\begin{array}{l}\text { - Muncul } \\
\text { halaman } \\
\text { detail } \\
\text { makanan }\end{array}$ & Sukses \\
\cline { 3 - 5 } & $\begin{array}{l}\text { Mengevalua } \\
\text { si makanan }\end{array}$ & $\begin{array}{l}\text { - Nilai } \\
\text { evaluasi } \\
\text { yang di } \\
\text { tambahkan }\end{array}$ & Sukses \\
\hline \multirow{2}{*}{5} & $\begin{array}{l}\text { Mengecek } \\
\text { Menu Hasil } \\
\text { Akhir }\end{array}$ & $\begin{array}{l}\text { - Membuka } \\
\text { halaman } \\
\text { hasil akhir }\end{array}$ & $\begin{array}{l}\text { - Muncul } \\
\text { halaman } \\
\text { hasil akhir }\end{array}$ & Sukses \\
\hline
\end{tabular}

\section{PENUTUP}

\section{A. Kesimpulan}

Berdasarkan hasil pembahasan Sistem Pendukung Keputusan Pemilihan Mahasiswa Berprestasi, maka dapat disimpulkan sebagai berikut:

1) Penelitian ini berhasil mengembangkan Sistem Pendukung Keputusan Rekomendasi Makanan Khas Sulawesi Utara yang Menunjang Diet dengan menerapkan metode $A H P$ untuk menghasilkan peringkat rekomendasi makanan yang menunjang diet.

2) Hasil akhir yang di dapat berupa hasil rangking ke 14 makanan khas sulawesi utara, makanan yang paling baik untuk diet adalah Nasi Jaha dengan skor 54.49.

3) Berdasarkan dari hasil perhitungan manual dan dari sistem mendapatkan hasil akhir yang sama.

4) Aplikasi Sistem Pendukung Keputusan yang dibangun dapat membantu, mempermudah, dan mempercepat bagi pengguna yang sedang melakukan diet dalam penentuan makanan diet yang telah di rekomendasi oleh sistem, namun sistem ini hanya sekedar alat pembantu dalam melakukan pengambilan keputusan, tidak sepenuhnya mengganti peran seorang ahli gizi dalam memberikan rekomendasi makanan diet.

\section{B. Saran}

Sistem pendukung keputusan rekomendasi makanan khas sulawesi utara yang menunjang diet yang telah di buat masih perlu dikembangkan agar kinerja sistem menjadi lebih baik, oleh karena itu disarankan untuk penelitan selanjutnya diharapkan data kriteria dan data makanan yang diperoleh bisa lebih baik dari sebelumnya, penambahan data penilaian kriteria umur dan jenis kelamin, serta hasil yang didapat bisa lebih baik lagi berupa rangking makanan yang sudah menjadi menu makanan dan pada sistem bisa ditambahkan gambar makanan sehingga sistem yang dibuat bisa lebih baik lagi.

\section{DAFTAR PUSTAKA}

[1] J. A. Andri Philip.2014.Analisa Perancangan Sistem Pendukung Keputusan Admisi Siswa Baru menggunakan Analytical Hierarcy Process di SMA Negeri 2 Manado.[Online]. Tersedia di: http://ejournal.unsrat.ac.id/index. php/informatika/article/view/4048/356427 Juni 2015.

[2] J. P. Muhammad. 2014. Aplikasi Bimbingan SkripsiOnlineMahasiswa Jurusan Pendidikan Matematika FakultasMatematika dan Ilmu Pengetahuan AlamaUniversitas Negeri Yogyakarta. Skripsi Program S1 Pendidikan Matematika Universitas Negeri Yogyakarta.

[3] K. M. Iqbal. 2016. Aplikasi Sistem Pakar Penentu Kesehatan Makanan Khas Sulawesi Utara Berbasis Android. Skripsi Program S1 Teknik Informatika Universitas Sam Ratulangi. Manado.

[4] N.Muchamad.2012.Pembangunan Sistem Informasi Presensi Siswa Pada Sekolah Menengah Atas (SMA) Negeri 1 Rembang Berbasis Finger Print.[Online].Tersedia di :http://ijns.org/journal/index.php/speed/ article/ view/109821 Maret 2016.

[5] P. Agung. 2012. Sistem Pendukung Keputusan Pemilihan Menu Diet pada Penyandang Diabetes Melitus dengan Logika Fuzzy Metode Sugeno dan Naive Bayes. Skripsi Program S1 Teknik Informatika Universitas Trunojoyo. Bangkalan.

[6] T. Kristanti and N. G. Redita A.K. 2012. Sistem Informasi Nilai SMPN 14 Bandung. Jurnal Sistem Informasi, Vol. 7, No. 1, 85 -94 .

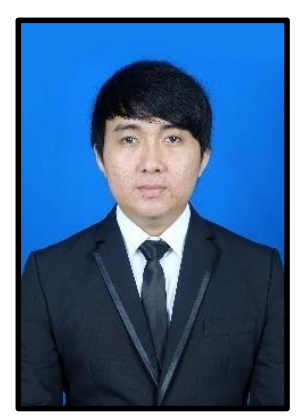

Sekilas dari penulis dengan nama lengkap Fernando Davidzon Sawel, lahir di kota Manado, Provinsi Sulawesi Utara. Anak ke-3 dari 3 bersaudara. Dengan pendidikan pertamadi Taman Kanak-Kanak Katolik SantaTheresia, Malalayang, Manado. Kemudian Melanjutkan keSekolah Dasar Negeri 126Manado. Kemudian Melanjutkan ke Sekolah Menengah Pertama KatolikSantu RafaelManado. Kemudian melanjutkan ke Sekolah Menengah AtasSMA Negeri9 Manado. Setelah lulus tahun 2011 melanjutkan ke Perguruan Tinggi di Universitas Sam Ratulangi Manado dengan mengambil Jurusan Teknik Informatika. Pada tahun 2015 bulan Juni, penulis membuat Skripsi demi memenuhi syarat Sarjana (S1) dengan penelitian berjudul Sistem Pendukung Keputusan Rekomendasi Makanan Khas Sulawesi Utara yang Menunjang Diet yang dibimbing oleh dua dosen pembimbing yaitu Alicia A. E. Sinsuw, ST., MT dan Muhamad D. Putro, ST., M.Eng sehingga pada tanggal 16September 2016 penulis resmi lulus di Teknik Informatika Universitas Sam Ratulangi Manado dan menyandang gelar Sarjana Komputer dengan predikat Sangat Memuaskan. 